\title{
APLIKABILITAS METODE APPLIED BEHAVIOR ANALYSIS UNTUK MENGURANGI PERILAKU ANAK ADHD \\ (Attention Deficit Hyperactivity Disorders)
}

\author{
Marlina, M.Si. \\ Dosen Tetap Jurusan Pendidikan Luar Biasa Universitas Negeri Padang
}

\begin{abstract}
Children who have attention deficit hyperactivity disorders (ADHD) often referred to as a hyperactive child. Children who have behavioral disorders generally have normal intelligence levels, but because the disorder, they show underachiever. This is because they are difficult to focus, concentrate, obey school rules, sit still in class (do not move the seat), and so forth. Applied behavior analysis methods can be used as an approach to solve the problem above. The approach used in the modification of behavior include: relaxation, systematic desensitization, sensitivity training, imitation through modeling, operant conditioning, self-control, saturation, assertiveness training, and conditioning through resistance. Of some of these approaches that are often used to change behavior in ADHD children is imitation through modeling, operant conditioning, immunization techniques, and assertiveness training.
\end{abstract}

Keywords : Applied behavior analysis and hyperactivity.

\section{Pendahuluan}

Setiap orang berupaya dalam kehidupannya berperilaku sesuai dengan tuntutan nilai-nilai dan norma-norma yang berlaku. Jika orang mampu berperilaku dan bersikap sesuai dengan tuntutan nilai-nilai dan norma yang ada, maka ia akan mudah melakukan aktivitas rutinnya, mudah bergaul dengan masyarakat, serta dapat berkomunikasi dengan orang lain di luar dirinya. Persoalannya, tidak semua orang dapat berperilaku dan bersikap sebagaimana harapan masyarakat pada umumnya. Ada beberapa orang yang tidak mampu berperilaku seperti yang diharapkan orang lain pada umumnya. Salah satu diantaranya adalah anak yang mengalami gangguan pemusatan perhatian dan hiperaktivitas (attention deficit byperactivity disorders). Anak ini sering disebut juga dengan anak hiperaktif atau anak yang mengalami gangguan perilaku. Anak ini mengalami kesulitan dalam 
memusatkan perhatian (inattention), tidak sabaran (impulsif) baik secara fisik maupun secara verbal, serta hiperaktivitas yang tinggi (Marlina, 2007).

Secara umum, anak yang mengalami gangguan perilaku ini memiliki tingkat kecerdasan yang normal, namun karena gangguan tersebut mereka menunjukkan underacbiever (prestasi yang dicapai berada di bawah kemampuan yang sebenarnya dimiliki). Hal ini disebabkan mereka sulit untuk memusatkan perhatian, berkonsentrasi, mematuhi aturan sekolah, tetap duduk di kelas (tidak berpindah-pindah tempat duduk), dan sebagainya. Di samping anak ADHD mengalami underachiever, perilaku hiperaktif juga berpengaruh terhadap relasi sosialnya, mereka dijauhi, disisihkan, diabaikan, bahkan ditolak teman sebayanya (Marlina, 2007). Kemungkinan lain yang dihadapi anak hiperaktif adalah pemberian label negatif oleh guru yang menyebabkan mereka stres dengan lingkungan sekolah, sehingga mereka banyak yang drop-out (Shepherd, 2010).

Jika dilihat dalam proses pembelajaran anak ADHD, guru lebih banyak menggunakan metode penugasan dan drill serta belum diterapkannya teknik dan pendekatan yang mampu mengeliminir perilaku hiperaktif anak tersebut. Anak hanya diberi tugas-tugas akademik, dilatih namun perilakunya tidak diperhatikan. Di samping itu guru juga lebih menekankan kepada penguasaan materi pada anak tanpa membenahi perilaku hiperaktif anak. Anak diberi materi pelajaran, di sisi lain anak berperilaku yang kurang diharapkan guru, akibatnya anak sering dimarahi, diberi label sebagai anak pembangkang, anak nakal, dan sebagainya.

Upaya penanganan terhadap anak-anak ADHD dari waktu ke waktu meningkat sejalan dengan perkembangan ilmu pengetahuan. Peningkatan tersebut dapat dilihat minimal dari dua sisi, yaitu yaitu dari segi preventif dan kuratif atau korektif. Upaya-upaya tersebut antara lain dilakukan dengan deteksi dini terhadap gangguan anak, intervensi dini terhadap kemungkinan yang akan terjadi pada perkembangan anak. Dari sisi kuratif penanganan perilaku anak-anak dengan gangguan pemusatan perhatian dan hiperaktivitas diarahkan untuk menyembuhkan dan memperbaiki perilaku-perilaku menyimpang yang terjadi pada anak. Dari sisi ini, penanganan anak dilakukan melalui berbagai pendekatan, baik medis maupun pedagogis-psikologis. Salah satu pendekatan pedagogis-psikologis adalah dengan metode applied bebavior analysis. 


\section{Gejala-Gejala dan Karakteristik ADHD}

Berdasarkan DSM IV (dalam Westwood, 1995) gejala ADHD, yaitu :

- Inatensivitas

Yakni tidak ada perhatian atau tidak menyimak. Penderita mengalami kesulitan dalam memusatkan perhatian terhadap sesuatu yang sedang dihadapinya. Ciri-cirinya adalah: 1) gagal menyimak hal yang rinci, 2) kesulitan bertahan pada satu aktivitas, 3) Tidak mendengarkan sewaktu diajak berbicara, 4) Sering tidak mengikuti instruksi, 5) kesulitan mengatur jadual tugas dan kegiatan, 6) sering menghindar dari tugas yang memerlukan perhatian lama, 7) sering kehilangan barang yang dibutuhkan untuk tugas, 8) sering beralih perhatian oleh stimulus dari luar, dan 9) sering pelupa dalam kegiatan sehari-hari.

- Impulsivitas

Kemampuan untuk mengontrol perilaku yang lebih mengutamakan untuk menuruti dorongan hati (tidak sabaran). Impulsif tersebut berupa impulsif motorik dan impulsif verbal atau kognitif, dengan ciri-ciri sebagai berikut: 1) sering memberi jawaban sebelum pertanyaan selesai, 2) sering mengalami kesulitan menunggu giliran, 3) sering memotong atau menyela orang lain, 4) sembrono, melakukan tindakan berbahaya tanpa pikir panjang, 5) sering berteriak di kelas, 6) tidak sabar, 7) usil/suka mengganggu siswa lain, 8) permintaannya harus segera dipenuhi, dan 9) mudah frustrasi dan putus asa.

- Hiperaktivitas

Tidak bisa diam, yaitu perilaku yang mempunyai kecenderungan melakukan suatu aktivitas berlebihan, baik motorik maupun verbal, dengan ciri-ciri: 1) sering menggerakkan kaki atau tangan dan sering menggeliat, 2) sering meninggalkan tempat duduk di kelas, 3) sering berlari dan memanjat, 4) mengalami kesulitan melakukan kegiatan dengan tenang, 5) sering bergerak seolah diatur oleh motor penggerak, dan 6) sering berbicara berlebihan.

Perbedaan jenis kelamin juga menentukan peluang perilaku hiperaktif. Anak laki-laki mempunyai kemungkinan 3 atau 4 kali 
lebih besar berperilaku hiperaktif dibanding anak perempuan. Kemungkinan tersebut terjadi karena anak perempuan sifat agresifnya tidak begitu berkembang. Selain itu anak laki-laki lebih mudah berperilaku agresif dibandingkan anak perempuan. Santrock (2002) membagi perilaku aktif yang berlebihan menjadi :

- Overaktivitas

Overaktivitas adalah perilaku tidak mau diam, yang disebabkan oleh himpunan energi yang berlebihan, yang merupakan suatu tanda bahwa anak tersebut sehat, cerdas, dan penuh semangat. Dalam waktu sesaat overaktivitas dapat dialami oleh anak-anak yang keaktifannya normal, kejadian ini disebabkan adanya ketegangan yang dialami anak.

- Hiperaktivitas

Hiperaktivitas adalah perilaku yang terjadi seperti perilaku overaktivitas, tetapi disertai tindakan yang tidak terarah dan berkepanjangan.

- Sindrom Hiperkinetik

Sindrom hiperkinetik adalah perilaku seperti pada hiperaktivitas yang parah, sering disertai dengan kelambatan dalam perkembangan psikologis, misalnya sifat kikuk dan kesulitan dalam bicara (speech delay).

Namun, hal lain yang harus diperhatikan adalah bahwa tidak semua gerakan fisik yang berlebihan merupakan hiperaktif, misalnya anak-anak usia 2 atau 3 tahun biasanya sangat aktif. Perilaku ini wajar karena dalam usia tersebut anak suka bereksplorasi, yaitu rasa ingin tahu yang cukup besar. Namun demikian, menurut Osman (2002), jika gerakan anak yang berlebih tersebut jauh lebih banyak dengan anak seusianya maka yang perlu diperhatikan adalah :

- Gerakan anak hiperaktif tidak terarah, tanpa tujuan dan tidak sesuai dengan situasi yang dihadapi. Biasanya mereka terus bergerak kesana kemari tanpa tujuan yang pasti, seolah-olah ada motor penggerak yang ada dalam dirinya.

- Anak tersebut sulit untuk memusatkan perhatian pada satu hal sehingga sering gagal dalam menyelesaikan tugasnya. 
Dalam membahas karakteristik ADHD di atas, ada 3 istilah yang sering muncul yakni, ciri-ciri primer, ciri-ciri sekunder, dan ciriciri khusus. Ciri-ciri primer merupakan karakteristik pokok anak ADHD yaitu 1) inatensivitas: tidak mampu memberikan perhatian, 2) impulsivitas: tidak sabaran, dan 3) hiperaktivitas. Sedangkan ciriciri sekunder merupakan akibat dari ciri-ciri pokok, yaitu 1) agresif, 2) gagal dalam kegiatan akademik, 3) hubungan dengan teman sebaya kurang baik, 4) koordinasi motorik kurang baik, dan 5) dan kurang disiplin.

\section{Metode Applied Behavior Analysis (ABA)}

Perilaku, kelakuan, atau tindak tanduk merupakan hasil interaksi seseorang dengan lingkungannya. Dalam pengertian luas, perilaku mencakup segala sesuatu yang dilakukan atau dialami seseorang. Dalam pengertian sempit, perilaku dirumuskan sebagai reaksi yang dapat diamati secara umum atau objektif (Chaplin, 2009). Modifikasi perilaku merupakan fokus dari model perilaku, yang berusaha mengubah perilaku yang tidak dikehendaki dengan menerapkan prinsip-prinsip belajar secara sistematis kearah cara-cara yang lebih adaptif.

Penerapan modifikasi perilaku menggunakan beberapa prinsip teori perilaku, Joyce \& Weil (1996) menyatakan: 1) perilaku sebagai sesuatu yang bisa diamati (observable) yakni gejala yang bisa diidentifikasi, 2) perilaku. yang maladaptif diperoleh melalui belajar dan dapat diubah dengan prinsip-prinsip belajar, 3) tujuan dari perilaku tersebut spesifik, deskrit dan individual, dan 4) teori perilaku menitikberatkan pada "saat kini dan di sini". Joyce \& Weil (1996) menambahkan bahwa teori perilaku terdiri dari dua model, yaitu: 1) model operant conditioning (Skinner), yang menekankan pada peran lingkungan (khususnya hadiah dan hukuman) dan 2) model counterconditioning (Wolpe), yakni menekankan pada prosedur penggantian perilaku adaptif menjadi respon yang maladaptif. Model yang digunakan dalam makalah ini adalah model operant conditioning (Skinner).

Pada dasarnya modifikasi perilaku diarahkan pada tujuan memperoleh perilaku yang baru, penghapusan perilaku yang maladaptif, mengurangi perilaku menyimpang serta memperkuat dan mempertahankan perilaku yang diinginkan. Salah satu bagian dari modifikasi perilaku adalah applied 
bebavior analysis yakni ilmu yang menerapkan secara sistematis prinsipprinsip keperilakuan untuk mengubah perilaku yang signifikan.

Cooper, dkk (2007) mendefinisikan applied bebavior analysis sebagai:

"the science in which tactics derived from the principles of behavior are applied systematically to improve socially significant behavior and experimentation is used to identify the variables responsible for bebavior change".

ABA didefinisikan sebagai ilmu yang menerapkan prinsip-prinsip perilaku secara sistematis untuk meningkatkan perilaku yang signifikan secara sosial dan menggunakan eksperimentasi untuk mengidentifikasi variabel-variabel yang bertanggung jawab terhadap perubahan perilaku. Menurut Slavin (1996) applied behavior analysis merupakan proses dalam mengaplikasikan prinsip-prinsip perilaku tentatif yang bertujuan untuk meningkatkan perilaku spesifik dan penilaiannya dilakukan secara simultan. Alberto \& Troutman (2008) mendefenisikan ABA sebagai penerapan yang sistematis dari prinsip-prinsip perilaku untuk mengubah perilaku menjadi bermakna secara sosial, serta memverifikasi kaitan antara perilaku dan intervensi yang diberikan.

Berdasarkan pendapat di atas dapat disimpulkan bahwa applied behavior analysis merupakan penerapan prinsip-prinsip dari teori perilaku yang bertujuan untuk mengubah, memperbaiki, dan meningkatkan perilaku spesifik menjadi perilaku perilaku yang diterima secara sosial.

\section{Langkah-langkah Penerapan Metode ABA}

Corey (1991) membuat langkah-langkah penerapan metode ABA sebagai berikut:

- Pertama, tahap classical conditioning, dihasilkan dari individu yang pasif, menekankan pada stimulus-respon. Pada tahap ini bagaimana memberikan situasi yang aman, bebas dari ancaman tidak rasa takut, memberikan stimulus agar respon yang diharapkan dapat muncul. Individu cenderung pasif sedangkan terapis lebih aktif.

- Kedua, tahap operant conditioning. Pada tahap ini terjadi perubahan perilaku dapat berfungsi sebagai penguat-ulang (reinforcer). Agar suatu perilaku yang diharap terus bertahan. Apabila suatu perubahan perilaku tidak menghasilkan penguat-ulang maka kecil 
kemungkinannya perilaku yang diharapkan itu muncul berubah. Tahap ini lebih menekankan pada respon.

- Ketiga, tahap kognitif behavioristik. Awalnya metode ABA mengesampingkan konsep berpikir (cognitive), konsep sikap dan konsep nilai. Namun, dalam perkembangan selanjutnya, mulai memperhatikan konsep berpikir (kognitif) dalam melakukan terapi. Konsep ini diberi nama terapi pengubah perilaku atau lebih dikenal dengan modifikasi perilaku. Modifikasi perilaku ini sebagai pengalaman dasar hasil penelitian dengan tujuan memgatasi masalah pribadi dan sosial serta meningkatkan fungsi dari modifikasi perilaku.

\section{Prinsip-Prinsip Penggunaan Metode ABA}

Metode ABA menggunakan pendekatan operant conditioning (Skinner). Metode yang digunakan adalah metode shaping, yaitu suatu metode pengarah perilaku. Perilaku-perilaku anak terus diarahkan menuju perilaku yang lebih adaptif. Pada pendekatan ini perilaku yang akan diubah dibagi dalam unit-unit atau bagian-bagian. Pengubahan perilaku dilakukan setiap bagian, dengan memberikan reinforcement setiap bagian setelah ada respon yang sesuai atau mendekati perilaku yang diharapkan. Apabila sudah berhasil baru menuju pada bagian selanjutnya, demikian seterusnya. Misalnya memperbaiki motorik halus melalui kegiatan menulis. Kegiatan menulis ini dibagi dalam beberapa bagian, mengambil pensil atau buku, meraut pensil, memegang pensil, menulis, menulis dengan aturan dan arahan guru. Anak diberi stimulus agar mau melakukan kegiatan ini bagian per bagian. Setelah bethasil melakukan kegiatan per bagian diberikan reinforcement sebagai penguat sampai pada tahap akhir, yaitu menulis berdasarkan aturan dan arahan guru.

Prinsip pelaksanaan shaping adalah penggunaan reinforcement dan extinction, merupakan alat yang dapat digunakan untuk membuat atau membentuk perilaku operant yang baru. Sebelum memulai membentuk perilaku, harus diyakini bahwa reinforcer (penguat) yang dipakai adalah efektif untuk mengubah perilaku yang dikehendaki. Shepherd (2010) menjelaskan agar metode shaping ini dapat terlaksana dengan baik jika dilakukan dengan memisahkan anak dari reinforcer untuk beberapa waktu 
sebelum shaping dimulai. Selanjutnya dianalisis perilaku sebenarnya yang akan dibuat.

Prosedur umum yang digunakan dalam shaping dimulai dengan memisahkan anak dari reinforcer, hal ini dimaksudkan untuk menaikkan tingkat aktivitas anak atau menaikkan respon. Respons yang mirip dengan respon yang diinginkan perlu diberikan reinforcement. Pemberian reinforcement yang selektif akan meningkatkan frekuensi dari variasi respon yang sudah diperkuat. Setelah perilaku yang kuat terbentuk dan berulangkali berlangsung, reinforcement dihentikan. Kalau terjadi penurunan perilaku, maka perlu diberikan reinforcement kembali dengan tespon yang lebih mendekati tujuan, terus dilakukan sampai respon menjadi benar-benar kuat sehingga sudah menjadi kebiasaan.

Extinction menunjukkan suatu prosedur dimana respon yang mulanya telah diperkuat tidak lagi diperkuat, akibat respon atau frekuensi operan akan menurun secara bertahap. Meskipun demikian perilaku itu tidak lenyap begitu saja, tetapi melalui setahap demi setahap. Extinction adalah menghapus respon atau mengurangi, mengeliminasi respon atau membawanya kembali ke tingkat semula sebelum adanya reinforcement. Extinction dapat menghasilkan turunnya frekuensi respon dan dapat kenaikan kegiatan merespons segera setelah extinction dimulai. Contohnya meningkatkan perilaku belajar, setelah terbentuk kebiasaan belajar, reinforcement yang dihentikan justru meningkatkan perilaku belajar, atau sebaliknya justru akan menurun bahkan hilang.

Berdasarkan uraian di atas tentang metode shaping, dapat disimpulkan ada tiga langkah pokok untuk melakukan metode shaping, yaitu :

- Analisis perilaku yang akan diubah itu ke dalam bagian-bagian atau unit-unit.

- Tentukan reinforcement yang akan diberikan.

- Tentukan cara, saat, dan jenis reinforcement.

Dalam menentukan jenis reinforcement perlu diingat setiap individu tidak sama. Ada anak yang senang diberi permen cokelat, ada yang suka diajak jalan-jalan, tetapi ada juga yang hanya diberi anggukan, senyuman sudah merupakan "reward" atau reinforcement positif, yang dapat menimbulkan, mempertahankan atau memperkuat perilaku yang diharapkan. 
Waktu pemberian reinforcement perlu diperhatikan. Reinforcement dapat diberikan setiap saat muncul respon yang dikehendaki, tetapi dapat juga diberikan dengan menentukan secara ratio, misalnya setelah sekian kali melakukan akan diberikan "reward". Reinforcement mempunyai fungsi mempertahankan respon atau perilaku yang dikehendaki dan mempercepat terjadinya respon atau perilaku yang dikehendaki. Terapi perilaku dan modifikasi perilaku perbedaannya tidak terlalu mendasar, bahkan dapat dikatakan tidak ada.

\section{Aplikabilitas Metode ABA pada Anak ADHD}

Metode $\mathrm{ABA}$ yang diterapkan pada anak $\mathrm{ADHD}$ menggunakan berbagai pendekatan. Shepherd (2010) mengemukakan pendekatan yang sering digunakan dalam modifikasi perilaku, yaitu: relaksasi, desensitisasi sistematik, latihan kepekaan, peniruan melalui model, operant conditioning, pengusaan diri, kejenuhan, pelatihan asertivitas, dan kondisioning melalui penolakan. Dari beberapa teknik tersebut yang sering digunakan untuk mengubah perilaku pada anak-anak ADHD adalah peniruan melalui model, operant conditioning, teknik pengebalan, dan pelatihan asertivitas. Adapun teknik-teknik tersebut akan dijelaskan sebagai berikut:

- Peniruan melalui Model

Salah satu teori Bandura adalah belajar model, yakni proses belajar melalui imitasi dengan mengamati model atau tokoh atau beberapa orang teladan yang berperan sebagai perangsang terhadap pikiran, sikap subjek pengamat tindakan sehingga akan terbentuk perilaku yang baru (Bandura, 1977). Dalam melaksanakan teknik modelling, ada 2 tahapan yang harus diperhatikan, Shepherd (2010) menyatakan sebagai berikut: 1) tahap pemilikan, yakni tahap masuknya perilaku dalam perbendaharaan perilaku subjek, subjek mengamati dan mempelajari perilaku model yang diamati: 2) tahap pelaksanaan, yakni subjek melakukan perilaku yang telah dipelajari dari model. Shepherd menambahkan ada beberapa langkah dasar yang perlu diperhatikan dalam mengimplementasikan prosedur modeling, yaitu : 1) mengenali dan menentukan perilaku awal (baseline) yang akan diubah melalui modeling, 2) menentukan prakiraan urutan perilaku yang akan diperagakan dari yang paling kecil tingkat resiko 
kecemasannya ke yang paling besar, dan 3) menentukan pengukuh (reinforcement) yang akan diberikan bila subjek berhasil melakukan apa yang dirancangkan, 4) melaksanakan rancangan prosedur modeling yang telah dirancang, 5) mengubah jadual pengukuh untuk memastikan bahwa perilaku telah dikuasai oleh subjek, dan 6) mempertahankan perilaku subjek yang telah terbentuk dan berupaya melakukan generalisasi perilaku yang telah dikuasai subjek.

- Operant Conditioning

Pendekatan ini ditandai dengan analisis deterministik dan eksperimental suatu perilaku. Selain itu juga ditandai adanya konsentrasi (pemusatan) pada suatu perilaku operant (respon). Penggunaan pendekatan ini hanya untuk perilaku yang dapat diamati, diukur dan direproduksi kembali. Flick (1998) menjelaskan langkah-langkah penanganan anak ADHD dengan menggunakan pendekatan operant conditioning, yaitu :

- Memahami perilaku hiperaktif, seperti: 1) tidak mampu berkonsentrasi, 2) kurang kontrol dalam berperilaku dan berbicara, 3) aktivitas sangat tinggi tanpa tujuan, 4) agresif, seperti memukul dan mengganggu teman, 5) tidak mau mengerjakan tugas-tugas dari guru, dan 6) tidak mau mengikuti aturan yang dibuat sekolah.

- Menentukan perilaku, aktivitas atau keterampilan yang akan diubah.

- Membagi perilaku yang akan diubah dalam unit-unit kecil.

- Menentukan reinforcement.

- Mengubah atau mengajarkan perilaku per bagian secara sistematik, terstruktur dan dapat dinilai.

- Memberikan bimbingan (bantuan + reinforcement), sedikit demi sedikit bantuan tersebut ditiadakan. Perlu sikap tegas dan disiplin dari guru. Pemberian reinforcement bisa negatif dan positif tergantung kondisi anak. Reinforcement positif misalnya: memberi kasih sayang, acungan jempol, memangku, memberi sesuatu yang disukai anak tetapi tidak membawa dampak negatif pada anak. Reinforcement negatif misalnya: menarik tangan, menginjak kaki (tanpa menimbulkan sakit) setiap anak akan pergi dari tempat duduk, melarang dengan tegas apabila anak melakukan sesuatu yang tidak dikehendaki dan sebagainya. 
Reinforcement pada anak hiperaktif sangat subyektif, masing-masing anak tidak sama.

- Teknik Pengebalan/Kejenuhan (Saturation)

Merupakan teknik dengan cara memberikan rangsang yang menimbulkan rasa takut atau cemas yang diberikan terus menerus. Pengalaman yang dianggap mencemaskan atau menakutkan tersebut tidak menimbulkan efek negatif pada anak. Flick (1998) menjelaskan langkah penanganan anak hiperaktif dengan menggunakan pendekatan ini adalah: 1) melatih dan membuat kondisi agar anak dalam keadaan rileks, 2) susun faktor-faktor hirarkis dari yang paling tidak menimbulkan ketakutan sampai yang paling menimbulkan ketakutan, dan 3) berikan pengalamanpengalaman tersebut secara hirarkhis sambil membawa anak dalam keadaan rileks.

- Pelatihan Asertivitas

Pelatihan asertivitas adalah prosedur pengubahan perilaku yang mengajarkan, membimbing, melatih dan mendorong anak untuk menyatakan dan berperilaku tegas dalam situasi tertentu. Perilaku asertif adalah perilaku antar personal yang melibatkan aspek kejujuran, keterbukaan pikiran, perasaan, yang dilakukan dengan mempertimbangkan perasaan dan kesejahteraan orang lain.

Morris (1985) menyatakan perilaku asertif digolongkan pada tiga kategori, yaitu: asertif penolakan, asertif pujian, dan asertif permintaan. Asertif penolakan dapat dilakukan dengan halus, misalnya "maaf". Pada anak hiperaktif, terapis dapat melakukan dengan tegas, misalnya "jangan", "tidak boleh!". Pada anak dapat dilatihkan untuk menyatakan "Maaf, saya tidak mau!". Asertif pujian ditandai dengan kemampuan untuk mengekspresikan perasaan setuju, cocok, senang, mencintai, memuji dan bersyukur. Perilaku ini lebih diarahkan pada kemampuan mengapresiasikan sesuatu yang dialami dalam dirinya. Misalnya, "Wah, ini cocok untuk kamu!". Sedangkan asertif permintaan merupakan latihan untuk meminta orang lain melakukan sesuatu untuk mencapai tujuan tertentu tanpa tekanan atau paksaan. Misalnya, "Apakah kamu mau menjelaskan mengapa memukul Annisa?”, dan sebagainya. 
Latihan asertif dapat dilakukan pada anak-anak yang: a) mengalami kesulitan untuk mengatakan "tidak", b) tidak dapat mengekspresikan perasaan marah atau tersinggung, c) kesulitan mengekspresikan perasaan dan respon-respon yang positif, d) terlalu sopan, dan e) merasa tidak dapat mengekspresikan perasaan dan pikiran.

\section{Penutup}

Aplikasi metode ABA dalam pendidikan sangat membantu penyelenggaraan pembelajaran bagi anak berkebutuhan khusus terutama dalam pengubahan dan pembentukan perilaku, meningkatkan perilaku ke arah yang lebih baik, penghapusan perilaku yang maladaptif, mengurangi perilaku menyimpang serta memperkuat dan mempertahankan perilaku yang diinginkan. Pelaksanaan metode ABA ditandai dengan perilaku yang tampak, spesifik, kecermatan dan penguraian tujuan treatmen, perumusan prosedur treatmen yang spesifik, dan adanya penafsiran objektif atas hasil terapi. Metode ini bertujuan untuk mengajarkan keterampilan yang dibutuhkan oleh anak supaya bisa kembali ke jalur perkembangan yang normal. Keterampilan yang diajarkan adalah kepatuhan, kemampuan berkomunikasi, sosialisasi, akademik, dan bantu diri.

Pelaksanaan metode ABA harus dilaksanakan dengan memecah keterampilan yang mau diajarkan menjadi beberapa bagian atau langkah-langkah kecil, yaitu : (1) terstruktur, yakni pengajaran menggunakan teknik yang jelas; (2) terarah, yakni ada kurikulum jelas untuk membantu mengarahkan terapi; dan (3) terukur, yakni keberhasilan dan kegagalan menghasilkan perilaku yang diharapkan, diukur dengan berbagai cara, tergantung kebutuhan. Artinya, mengajarkan suatu keterampilan sampai terkuasai, memberi pengulangan, menyediakan prompt (bantuan), menghilangkan ketergantungan dan pemberian reinforcerment.Metode Applied Behavior Analysis pada anak ADHD, mesti mendasarkan proses pengajaran pada pemberian stimulus (instruksi), respon individu (perilaku) dan konsekuensi (akibat perilaku). Ketika melaksanakan metode ini, guru mesti konsisten memberikan stimulus, respon dan konsekuensi yang diberikan. Selain itu, dibutuhkan juga kemampuan ( $s k i l h$, pengetahuan memadai tentang ADHD dan teknik ABA (knowledge). Terakhir, bersikap baik, optimis 
dan memiliki minat perasaan (sense) terhadap anak-anak ADHD sangat menentukan proses pemberian bantuan yang berkelanjutan.

\section{Daftar Pustaka}

Alberto \& Troutman. 2008. Some Current Dimensions of Applied Behavior Analysis. Journal of Applied Behavior Analysis, 1, 91-97. Alonzo, BD. 1996. Identification and Education of Students with Attention Deficit Hyperactive Disorders: Preventing School Failure. Special Education at New Mexico State University.

Corey. 1991. Theory and Practice of Counseling and Psychotherapy. California: Brooks Publishing Company.

DuPaul, J.G \& Stoner G. 1994. Attention Deficit Hyperactive Disorders: Classroom Intervention Strategies. School Psychology International, 12, 85-94. Farnham, S \& Diggory. 1994. The Learning Disabled Child. England: Harvard University Press.

Flick, Grad L. 1998. ADD/ADHD Behavior-Change Resource Kit: Ready to Use Strategies \& Activities for Helping Children with Attention Deficit Disorder. New York: The Center for Applied Research in Education.

Heward, W. L., Heron, T. E., Neef, N. A., Peterson, S. M., Sainato, D. M., Cartledge, G. 2005. Focus on Behavior Analysis in Education: Achievements, Challenges, and Opportunities. Upper Saddle River. New Jersey: Prentice Hall.

Joyce, Bruce \& Weil, Marsha. 1996. Models of Teaching Fifth Edition. Boston : Allyn and Bacon.

Marlina. 2007. Asesmen dan Strategi Intervensi Anak ADHD (Attention Deficit Hyperactivity Disorders). Jakarta: Depdiknas Direktorat Pembinaan Pendidikan Tenaga Kependidikan dan Ketenagaan Perguruan Tinggi.

Morris, Richard Y. 1985. Behavior Modification with Exceptional Children. Illinois: Scott Foresman and Company. 
Osman, Betty B. 2002. Lemah Belajar dan ADHD: Panduan Hidup Keluarga dan Belajar Bersama. Jakarta: Grasindo.

Quay \& Werry. 1986. Psychopathological Disorders of Childhood. Canada: John Willey \& Sons Inc.

Rief, S.F \& Heimburge, J.A. 1996. How to Reach \& 'Teach All Students in The Inclusive Classroom: Ready-to-Use, Lessons and Activities for Teaching Students with Diverse Learning Needs. San Francisco: John Wiley \& Sons Inc.

Santrock, J.W. 2002. Life Span Development Perkembangan Masa Hidup. (Alih Bahasa Achmad Chusairi dan Juda Damanik). Jakarta: Erlangga.

Shepherd, Tery L. 2010. Working with Students with Emotional and Behavior Disorders: Characteristics and Teaching Strategies. New Jersey: Pearson Education Inc.

Slavin, Robert E. 1996. Educational Psychology: Theory into Practice. Massachusetts: Allyn \& Bacon.

Taylor, E. 1992. Anak Hiperaktif Tuntunan bagi Orangtua (terjemahan Alex Tri Kanjono). Jakarta: Gramedia Pustaka Utama.

Taylor, Ronald L. 2000. Assessment of Exceptional Students: Educational and Psychological Procedures. Florida Atlantic University: Allyn and Bacon.

Westwood, P. 1997. Commonsense Methods for Children with Special Needs. New York: Routledge. 